Research article

\title{
EFFECTS OF SELENIUM AND THYROID HORMONE DEFICIENCY ON PERITONEAL MACROPHAGES ADHESION AND OCCURRENCE OF NATURAL IgM ANTIBODIES IN JUVENILE RATS
}

\author{
BJELICA Jelena ${ }^{1}$, JOVANOVIĆ Ivan B. ${ }^{2}$, ILIĆ Vesna ${ }^{3}$, VALČIĆ Olivera ${ }^{2}$, KIROVSKI \\ Danijela $^{2}$, GVOZDIĆ Dragan ${ }^{4}$, MLANOVIĆ Svetlana ${ }^{2 *}$
}

${ }^{1}$ Medicine and Medical Devices Agency of Serbia, Belgrade, Serbia; ${ }^{2}$ Department of Physiology and Biochemistry, Faculty of Veterinary Medicine, University of Belgrade, Belgrade, Serbia; ${ }^{3}$ Institute for Medical Research, University of Belgrade, Belgrade, Serbia; ${ }^{4}$ Department of Pathophysioplogy, Faculty of Veterinary Medicine, University of Belgrade, Belgrade, Serbia

(Received 07 March, Accepted 206 June 2017)

Both selenium, as an effector and regulator of antioxidative enzymes activity, and thyroid hormones are potent immunomodulators. Besides, selenium incorporated into iodothyronine deiodinases is involved in the thyroid function and thus indirectly regulates the immune response. Studies of the mutual influence of selenium and thyroid hormones on the immune response are scarce, hence we analyzed the effects of an iodothyronine deiodinases blocker, propylthiouracil (PTU), and selenium deficiency on the function of peritoneal macrophages, and titer of naturally occurring anti-sheep red blood cells (SRBC) IgM antibodies in juvenile rats.

The experiment was carried out on 64 Wistar male rats allotted to 4 groups: controlselenium adequate PTU- group; selenium adequate, PTU+ group; selenium deficient, PTU- group; and selenium deficient, PTU+. The selenium adequate and selenium deficient groups were fed a diet containing 0.334 and $0.031 \mathrm{mg} \mathrm{Se} / \mathrm{kg}$, respectively. PTU+ groups received PTU $(150 \mathrm{mg} / \mathrm{L})$ in drinking water. After 3 weeks, thyroxine $\left(\mathrm{T}_{4}\right)$, triiodothyronine $\left(\mathrm{T}_{3}\right)$, and thyroid stimulating hormone $(\mathrm{TSH})$ were determined. The animals having "intermediate" concentrations of $\mathrm{T}_{3}(1.56-1.69 \mathrm{nmol} / \mathrm{L})$ and $\mathrm{T}_{4}$ $(41-50 \mathrm{nmol} / \mathrm{L})$ were excluded from further analysis. Thus, PTU+ groups included hypothyroid animals $\left(\mathrm{T}_{3} \leq 1.55 \mathrm{nmol} / \mathrm{L} ; \mathrm{T}_{4} \leq 40 \mathrm{nmol} / \mathrm{L}\right)$, while PTU- groups included euthyroid rats $\left(\mathrm{T}_{3} \geq 1.70 \mathrm{nmol} / \mathrm{L} ; \mathrm{T}_{4} \geq 50 \mathrm{nmol} / \mathrm{L}\right)$. Both groups of selenium deficient rats had, when compared to the control group, a significantly lower activity of glutathione peroxidase GPx1 and GPx3. Neither selenium deficiency nor PTU influenced the adherence of peritoneal macrophages. Selenium deficiency significantly decreased the peroxide synthesis in macrophages and significantly increased the titer of anti-SRBC IgM. Hypotyroidism alone or in combination with selenium deficiency had no influence on these parameters.

Key words: glutathione peroxidase, IgM, macrophage adherence, macrophage peroxide production, rats, selenium, thyroid hormones

\footnotetext{
*Corresponding author: e-mail: cecam@vet.bg.ac.rs
} 


\section{INTRODUCTION}

Selenium is an essential microelement which achieves its biological effects in the form of selenocysteine incorporated into selenoproteins. Selenium is an important member of the antioxidative systems and improves the parameters of oxidative and general stress. At the same time it is crucial for optimal functioning of the endocrine and immune systems [1,2].

Selenium status is of great significance for the function of the immune system. Data showed that selenium deficiency is accompanied with an inefficient immune response to various antigens (viruses, tumors, allergens) [3,4], and development of autoimmune diseases [5,6]. Most of its immunomodulatory effects have been explained by its role in antioxidant protection, i.e. in controlling the activities of reactive oxygen species (ROS)-mediated glutathione peroxidases (Gpx) and thioredoxin reductase. Selenium deficiency results in an inadequate activity of reactive oxygen species (ROS), controlling selenoproteins, and oxidative stress mediated cells damage or, in the case of selenium excess, reduced microbicidal effect of neutrophils, monocytes/macrophages and NK cells [2,7-10]. Selenium influences cells of adaptive immunity and its deficiency is accompanied by a reduced number of $T$ lymphocytes [11] and their decreased proliferation and differentiation [12-14]. Selenium deficiency also reduces the number of B lymphocytes but it`s effect on antibody synthesis is antigen dependent [10].

Thyroid hormones are unambiguously confirmed as powerful regulators of the immune response, able to modulate the activity of both innate and adaptive immune systems [15]. After binding to specific receptors expressed on immune cells of hematopoietic origin and/or on non-hematopoietic immunoregulatory cells, thyroid hormones modulate cell signaling, which results in the modulated expression of various membrane antigens, secretion of cytokines and other pro- and antiinflammatory mediators [15]. Hypothyroidism is accompanied with an increased proinflammatory activity (increased phagocytosis and increased ROS generation) of macrophages and neutrophils, depressed activity of NK cells, increased maturation of antigen presenting dendritic cells, and reduced number and lower effector function of T lymphocytes [15-18]. Data on the effect of hypothyroidism on humoral immunity are often contradictory and depend on the implemented experimental protocols and analyzed antigens [15].

Selenium is an integral component of all three iodothyronine deiodinases. Iodothyronine deiodinases are enzymes involved in the process of activation and inactivation of thyroid hormones $[4,19,20]$. By regulating the activity of thyroid hormones selenium indirectly regulates the immune response. The discovery of this function of selenium has pointed to the need for re-evaluation of previous data and re-interpretation of the mechanisms of immune regulation mediated by selenium and thyroid hormones. We performed this study in order to explore the mechanisms of interaction between these two immune regulatory systems and to define their individual and cross effects on the components of the immune system involved in the recognition and 
elimination of previously encountered antigens: macrophages and naturally occurring IgM antibodies. Macrophages are potent and long-lived phagocytes which within the immune system function as sentinel cells and antimicrobial effector cells, providing the second line of innate immune defense. Besides, they regulate adaptive immunity by acting as antigen presenting cells and secreting numerous pro- and anti-inflammatory mediators [21-23]. Naturally occurring IgM antibodies are mainly secreted by selfrenewing B-1 lymphocytes, without requirement for exogenous antigenic stimulation. Thanks to their low specificity they can recognize a wide range of evolutionary conserved polysaccharides and lipids of microbial antigens and some autoantigens, and provide the first line of defense against invading pathogens. Naturally occurring IgM antibodies directly neutralize or inhibit pathogens, aid the synthesis of immune IgM and $\mathrm{IgG}$ antibodies, and together with them protect the organism from bacterial and viral infections. Moreover, naturally occurring IgM suppress inflammatory responses initiated by mechanisms of innate and adaptive immunity (both $\mathrm{T}$ and $\mathrm{B}$ cell dependent) and protect from uncontrolled inflammation and development of inflammatory and autoimmune diseases [24-26]. However, when precise control of immunological reactivity is lost, as in selenium deficiency and hypothyroidism, both macrophages and naturally occurring IgM can be factors contributing to the development of longterm uncontrolled inflammation and autoimmune diseases [21,24-26]. Therefore, we performed this study, using a juvenile rat model, with the aim to analyze if individual and combined effects of nutritional selenium deficiency and chemically PTU- induced hypothyroidism modulate the function of peritoneal macrophages (adherence and peroxide production) and synthesis of naturally occurring $\operatorname{IgM}$ antibodies reactive to membrane antigens of sheep red blood cells (SRBC).

\section{MATERIAL AND METHODS}

\section{Animals and experimental design}

The experiment was designed as a group-control system on 64 male Wistar rats, 21 days old, weighing $48.6 \pm 7.8 \mathrm{~g}$, Charles-River origin (Hungary). The use of animals was approved by the Ethical Committee of the Faculty of Veterinary Medicine, University of Belgrade in accordance with the National Regulation on Animal Welfare.

Rats were supplemented either with selenium or propylthiouracil (PTU). Selenium adequate groups were fed a specially formulated feed containing $0.334 \mathrm{mg} \mathrm{Se} / \mathrm{kg}$ (C1000, Altromin, Germany), and selenium deficient groups were fed a diet containing $0.031 \mathrm{mg} \mathrm{Se} / \mathrm{kg}$ (C-1045, Altromin, Germany). PTU+ groups received PTU (Sigma) in drinking water at a concentration of $150 \mathrm{mg} / \mathrm{L}$, while PTU- groups were given pure drinking water. Four different groups were formed: (1) control group - selenium adequate, PTU-group ( $\mathrm{Se}_{\text {adeq }}$ PTU-); (2) selenium adequate, PTU+ group ( $\mathrm{Se}_{\text {adeq }} \mathrm{PTU}+$ ); (3) selenium deficient, PTU--group ( $\mathrm{Se}_{\text {def }}$ PTU-); (4) selenium deficient, PTU+ -group $\left(\mathrm{Se}_{\mathrm{def}} \mathrm{PTU}+\right)$. 
After a period of three weeks the rats were anesthetized with ether. Approximately $5 \mathrm{~mL}$ of blood was sampled by cardiac puncture into glass tubes containing heparin $(15 \mathrm{IU} / \mathrm{mL})$. Selenium concentration and activity of glutathione peroxidase (GPx1) were determined in the whole blood samples. The blood plasma was obtained by centrifugation for $20 \mathrm{~min}$ at $1000 \mathrm{x}$ g. Plasma samples were stored at $-20^{\circ} \mathrm{C}$ for the determination of concentration of triiodothyronine $\left(\mathrm{T}_{3}\right)$, thyroxin $\left(\mathrm{T}_{4}\right)$, and thyroid - stimulating hormone (TSH), glutathione peroxidase 3 activity (GPx3), and the concentration of anti SRBC IgG and IgM antibodies.

\section{Concentration of $\mathrm{T}_{3}, \mathrm{~T}_{4}$, and TSH}

Concentrations of free and bound $\mathrm{T}_{3}$ and $\mathrm{T}_{4}$ were measured using commercial RIA kits (INEP, Zemun, Serbia). The concentration of TSH was measured using RIA kits produced by MP Biomedicals, Belgium. The radioactivity of the sediment was measured with a gamma scintillation counter CompuGamma LKB (Belgium).

\section{Concentration of selenium, GPx1 and GPx3}

Whole blood selenium concentration was measured using the hydride technique, on the atomic absorption spectrophotometer (Thermo electron Solar AA, Series 4) with a hydride module and electrical heating of quartz cuvettes in an EC 90 furnace. Quality control was carried out with the aid of the referent material BCR 185 (IRMM, Belgium). The obtained values in replicate were within the range of the certified values.

Glutathione peroxidases activities were measured in whole blood and plasma samples using a coupled test as described by Gunzler et al. [27], modified by Sankari [28]. All chemicals were obtained from Sigma Aldrich. Blood samples were hemolysed using Drabkin's reagent (1.6 mM KCN, $1.2 \mathrm{mM} \mathrm{K}_{2} \mathrm{Fe}(\mathrm{CN})_{6}$ and $\left.0.023 \mathrm{M} \mathrm{NaHCO}_{3}\right)$. The final concentrations of the used reagents were: $100 \mathrm{mM}$ phosphate buffer $(\mathrm{pH} 7.4)$, $4 \mathrm{mM}$ ethylenediaminetetraacetic acid (EDTA), $6 \mathrm{mM}$ glutathione (GSH), $0.375 \mathrm{IU} /$ $\mathrm{mL}$ glutathione reductase (GR), $0.3 \mathrm{mM}$ reduced nicotinamide adenine dinucleotide phosphate (NADPH) and $1.575 \mathrm{mM}$ tertiary butyl hydroperoxide (TBH). The low concentration of TBH ensures that only the activity of selenium-dependent GPx enzymes is registred. The decrease in NADPH concentration was measured for $3 \mathrm{~min}$ at $366 \mathrm{~nm}$ using a Cecil Ce2021 spectrophotometer with a Peltier thermostat unit. The activity of GPx1 and GPx3 was expressed in $\mu$ kat/L.

\section{Assays for peritoneal macrophages adherence and peroxide production}

Peritoneal macrophages were induced by intraperitoneal application of $8 \mathrm{~mL}$ of filtered $2.4 \%$ thioglycollate medium seven days prior to sacrifice. After sacrifice the abdominal cavity was lavaged with $15 \mathrm{~mL}$ sterile PBS and then centrifuged at $500 \mathrm{xg}$ for $10 \mathrm{~min}$. The cell pellet was diluted in $2 \mathrm{~mL}$ PBS. Cell concentration was determined using manual hemocytometer and then diluted with PBS at a concentration of $2.5 \times 10^{6} / \mathrm{mL}$. 
Adhesion of peritoneal macrophages to plastic (polystyrene) was assessed with an in vitro spectrophotometric assay performed in 96 flat bottom microtiter plates [29]. The assay was carried out in such a way that $50 \mu \mathrm{L}$ of buffer was added per well, and then $50 \mu \mathrm{L}$ of the macrophages suspension was placed in each well. The final concentration of macrophages was $1.25 \times 10^{6} / \mathrm{L}$. The cells were incubated at $37^{\circ} \mathrm{C}$ for 10,30 , and 60 minutes, rinsed with warm $\left(37^{\circ} \mathrm{C}\right) \mathrm{PBS}$, fixed with $100 \mu \mathrm{L}$ methanol for 6 minutes, and stained by adding $100 \mu \mathrm{L} 0.1 \%$ filtered methylene blue. After 10 minutes the plates were rinsed with water until discolored and dried overnight at $37{ }^{\circ} \mathrm{C}$. After drying the dye was dissolved with $0.1 \mathrm{M} \mathrm{HCl}$ and the plates were incubated at $37^{\circ} \mathrm{C}$ in a humid chamber for $4 \mathrm{~h}$. The intensity of the developed color was measured on a microplate reader (GDV, Microplate Reader DV 990 BV 4/6, Italy) at $620 \mathrm{~nm}$.

The capacity of induced peritoneal macrophages to generate peroxide production was tested in vitro where the production of $\mathrm{H}_{2} \mathrm{O}_{2}$ was stimulated with phorbol miristate acetate (PMA). The method is based on the peroxidase-dependent transformation of phenol-red in a compound with an enhanced absorbance at 600-610 nm [30]. In brief: $100 \mu \mathrm{L}$ of the prepared peritoneal macrophages suspension was added to each well. After $2 \mathrm{~h}$ incubation at $37^{\circ} \mathrm{C}$ the non-adherent cells were removed by double washing with Minimum Essential Medium. The peroxide production was stimulated with 100 $\mu \mathrm{L} 25 \mathrm{nM}$ PMA in phenol-red. Immediately after plating the cells, $\mathrm{H}_{2} \mathrm{O}_{2}$ production was stopped by adding $10 \mu \mathrm{L} \mathrm{NaOH}$. The plates were incubated for $1 \mathrm{~h}$ at $37^{\circ} \mathrm{C}$ and the reaction was stopped with $10 \mu \mathrm{L} \mathrm{NaOH}$. Optical density (OD) was measured at 620 and $690 \mathrm{~nm}$. The standard curve for the determination of the production of $\mathrm{H}_{2} \mathrm{O}_{2}$ was constructed according to standard $\mathrm{H}_{2} \mathrm{O}_{2}$ solutions in the concentration range of $1-40 \mu \mathrm{M}$.

\section{Determination of titer of anti-sheep red blood cells (SRBC) IgM and IgG antibodies in rat plasma}

Titers of anti-SRBC IgM and IgG antibodies in rat plasma were determined with commercial ELISA kits: Rat Anti-SRBC IgM ELISA Kit (Life Diagnostics, Inc. West Chester, PA, USA) and Rat Anti-SRBC IgG Kit (Life Diagnostics, Inc. West Chester, PA, USA). ELISA plates were coated with SRBC membranes (antigens). ELISA was performed according to the manufacturer's instructions. In brief: diluted rat plasma (1:50) and serially diluted standard rat sera containing anti-SRBC IgM and IgG antibodies (3-50 U/mL 50 anti-SRBC IgM and 6-50 U/mL 50 anti-SRBC IgG) were incubated with coated antigen. After $45 \mathrm{~min}$ incubation and removal of unbound proteins the plates were incubated with secondary anti-rat IgM or anti-rat IgM conjugated with horseradish peroxidase. The reaction of SRBC antigens and specific antibodies was visualized using a peroxidase substrate 3,3',5,5'-tetramethylbenzidine (TMB). The reaction products were measured on the multi-plate reader at OD 450 $\mathrm{nm}$ and the results were given as $\mathrm{U} / \mathrm{mL}$ of specific anti-SRBC IgM and anti-SRBC $\mathrm{IgG}$. The results were calculated based on the standard curve constructed by plotting a series of $\operatorname{IgM}$ and $\operatorname{IgG}$ standard sera dilutions. 


\section{Statistical analysis}

Statistical analysis was carried out using MS Excel 2007 and Graph Pad Prism 5 statistical software packages. The data were tested for homogeneity and normality. As average values, arithmetic means were determined for homogeneous data and medians for heterogeneous values in a group. Therefore, we have presented both arithmetic means \pm SD and medians. The significance of the differences between average values/ medians was evaluated by using Student's t-test for homogenous and Mann Whitney $\mathrm{U}$ test for heterogeneous data. Results were deemed as statistically significant when the $\mathrm{p}$ value was $<0.05$. Correlations between selected parameters were tested by linear regression analysis.

\section{RESULTS}

As presented in the Material and Method section, hypothyreosis was induced with PTU. Animals not treated with PTU were considered as euthyroid. Nevertheless, all the animals having "intermediate" concentrations of $\mathrm{T}_{3}$ (range $1.56-1.69 \mathrm{nmol} / \mathrm{l}$ ) and $\mathrm{T}_{4}$ (the range 41-50 nmoL) were excluded from further analysis, after blood analyses on thyroid status. Thus, PTU+ groups included only hypothyroid animals $\left(\mathrm{T}_{3} \leq 1.55\right.$ $\mathrm{nmol} / \mathrm{L}$ and $\left.\mathrm{T}_{4} \leq 40 \mathrm{nmol} / \mathrm{L}\right)$, while PTU- groups included euthyroid rats $\left(\mathrm{T}_{3} \geq 1.70\right.$ $\mathrm{nmol} / \mathrm{L}$ and $\left.\mathrm{T}_{4} \geq 50 \mathrm{nmol} / \mathrm{L}\right)$. The data showed, as expected, that concentrations of $\mathrm{T}_{4}$ and $\mathrm{T}_{3}$ were significantly lower in groups treated with PTU. Also, in these groups, the level of TSH was significantly higher compared to PTU non treated groups (Table 1).

Table 1. Influence of selenium deficiency and PTU on blood selenium concentration and activity of erythrocyte cytosolic glutathione peroxidase (GPx1) and blood plasma glutathione peroxidase $(\mathrm{GPx} 3)$

\begin{tabular}{lcccc}
\hline & \multicolumn{2}{c}{ Selenium adequate } & \multicolumn{2}{c}{ Selenium deficient } \\
\cline { 2 - 5 } & $\begin{array}{c}\text { Euthyroid } \\
(\mathbf{n}=\mathbf{1 4})\end{array}$ & $\begin{array}{c}\text { Hypothyroid } \\
(\mathbf{n}=\mathbf{1 0})\end{array}$ & $\begin{array}{c}\text { Euthyroid } \\
(\mathbf{n}=\mathbf{1 5})\end{array}$ & $\begin{array}{c}\text { Hypothyroid } \\
(\mathbf{n}=\mathbf{7})\end{array}$ \\
\hline Se $(\mu \mathrm{g} / \mathrm{L})$ & $360 \pm 113$ & $369 \pm 129$ & $61 \pm 11^{\mathrm{c}}$ & $71 \pm 20^{\mathrm{c}}$ \\
$\mathrm{GPx} 1(\mu \mathrm{kat} / \mathrm{L})$ & $166 \pm 43$ & 291 & 63 & 71 \\
& 170 & $159 \pm 43$ & $59 \pm 19 \mathrm{c}$ & $109 \pm 36^{\mathrm{a}}, \#$ \\
$\mathrm{GPx} 3(\mu \mathrm{kat} / \mathrm{L})$ & $55.3 \pm 17.8$ & $83.2 \pm 25.0^{\mathrm{a}}$ & $37.4 \pm 19.8^{\mathrm{b}}$ & $46.1 \pm 11.3^{\mathrm{a}}$ \\
& 63.3 & 83.2 & 30.7 & 41.1 \\
\hline
\end{tabular}

The summary data are presented as the mean $\pm \mathrm{SD}$ and median

(a) $-\mathrm{p}<0.05$; (b) $-\mathrm{p}<0.01$; (c) $-\mathrm{p}<0.001$ compared to control selenium adequate, euthyroid group; (\#) $-\mathrm{p}<0.01$; compared to selenium deficient, euthyroid group.

For the assessment of selenium status of experimental rats, whole blood selenium concentration and erythrocyte glutathione peroxidase (GPx1), as well as plasma glutathione peroxidase (GPx3) activities were measured (Table 2). There were no statistically significant differences in whole blood selenium concentrations between selenium adequate groups. Selenium deficient rats had significantly lower selenium 
concentrations than selenium adequate rats. There was no significant difference in Se concentration between PTU- and PTU+ rats. Likewise, GPx1 and GPx3 activities were significantly higher in selenium adequate than Se deficient rats. Although both groups of selenium deficient rats had, comparing to the control group, a lower activity of GPx1, the activity was higher in PTU treated, selenium deficient rats. Besides, GPx3 activity in selenium adequate, PTU+ rats was higher than in the control group.

Table 2. Influence of selenium deficiency and PTU on the concentration of thyroxin (T4), triiodothyronine (T3), and thyroid stimulating hormone (TSH).

\begin{tabular}{lcccc}
\hline & \multicolumn{2}{c}{ Selenium adequate } & \multicolumn{2}{c}{ Selenium deficient } \\
\cline { 2 - 5 } & $\begin{array}{c}\text { Euthyroid } \\
(\mathbf{n}=\mathbf{1 4})\end{array}$ & $\begin{array}{c}\text { Hypothyroid } \\
(\mathbf{n}=\mathbf{1 0})\end{array}$ & $\begin{array}{c}\text { Euthyroid } \\
(\mathbf{n}=\mathbf{1 5})\end{array}$ & $\begin{array}{c}\text { Hypothyroid } \\
(\mathbf{n}=\mathbf{8})\end{array}$ \\
\hline \multirow{2}{*}{$\mathrm{T} 4(\mathrm{nmol} / \mathrm{L})$} & $90.7 \pm 22.0$ & $22.7 \pm 11.3 \mathrm{c}$ & $90.4 \pm 14.1$ & $20.0 \pm 12.1^{\mathrm{c}}$ \\
& 88.7 & 25.4 & 91.9 & 14.9 \\
$\mathrm{~T} 3(\mathrm{nmol} / \mathrm{L})$ & $2.27 \pm 0.26$ & $0.82 \pm 0.44 \mathrm{c}$ & $2.14 \pm 0.26$ & $0.86 \pm 0.42^{\mathrm{c}}$ \\
& 2.27 & 0.70 & 2.09 & 0.88 \\
$\mathrm{~T} S H(\mathrm{ng} / \mathrm{L})$ & $4.1 \pm 2.7$ & $82.8 \pm 10.3 \mathrm{c}$ & $5.6 \pm 2.9$ & $86.3 \pm 9.4 \mathrm{c}$ \\
& 4.2 & 84.0 & 5.1 & 90.0 \\
\hline
\end{tabular}

The summary data are presented as the mean \pm SD and median. ( $\left.^{c}\right)-p<0.001$ compared to control selenium adequate, euthyroid group.

The spontaneous (non-stimulated) adherence of peritoneal macrophages in the control group was equal at all estimated times. The recorded $\mathrm{OD}_{620}$ values were $0.043 \pm 0.004,0.047 \pm 0.006$, and $0.051 \pm 0.012$, for 10,30 and $60 \mathrm{~min}$. incubation. There were no statistically significant differences in the adherence of peritoneal macrophages between different groups after 10,30 (data not shown) and 60 min incubation (Table 3). Macrophages peroxide production was significantly higher in selenium adequate rats, but there was no significant difference between PTU- and PTU+ animals (Table 3). A significant correlation between the macrophages adherence and selenium concentration was not found $(\mathrm{R}=0.194 ; \mathrm{p}>0.10 ; \mathrm{n}=27$ ) (Figure $1 \mathrm{~A})$, but the level of peroxide synthesis in peritoneal macrophages significantly correlated with selenium concentration $(\mathrm{R}=0.44 ; \mathrm{p}<0.02 ; \mathrm{n}=29)$ (Figure 1B).

Table 3. Influence of selenium deficiency and PTU on $60 \mathrm{~min}$ peritoneal macrophage adherence and peroxide production in vitro.

\begin{tabular}{lcccc}
\hline & \multicolumn{2}{c}{ Selenium adequate } & \multicolumn{2}{c}{ Selenium deficient } \\
\cline { 2 - 5 } & $\begin{array}{c}\text { Euthyroid } \\
(\mathbf{n}=\mathbf{1 4})\end{array}$ & $\begin{array}{c}\text { Hypothyroid } \\
(\mathbf{n}=\mathbf{1 0})\end{array}$ & $\begin{array}{c}\text { Euthyroid } \\
(\mathbf{n}=\mathbf{1 5})\end{array}$ & $\begin{array}{c}\text { Hypothyroid } \\
(\mathbf{n}=\mathbf{8})\end{array}$ \\
\hline Adherence & $0.051 \pm 0.010$ & $0.051 \pm 0.003$ & $0.070 \pm 0.030 \ddagger$ & $0.060 \pm 0.015$ \\
(OD620) & 0.046 & 0.052 & 0.046 & 0.052 \\
Peroxide & $4.1 \pm 2.9$ & $4.7 \pm 4.1$ & $1.2 \pm 0.8$ & $1.2 \pm 0.9$ \\
$(\mu \mathrm{M})$ & 3.3 & 3.4 & $1.0^{\mathrm{b}}$ & $0.6^{\mathrm{b}}$ \\
\hline
\end{tabular}

The summary data are presented as the mean \pm SD and median. (b) $-\mathrm{p}<0.01$ compared to control selenium adequate, euthyroid group; $(\ddagger)$ - Difference between euthyroid, selenium adequate and selenium deficient groups close to statistically significant, $\mathrm{p}=0.08$. 

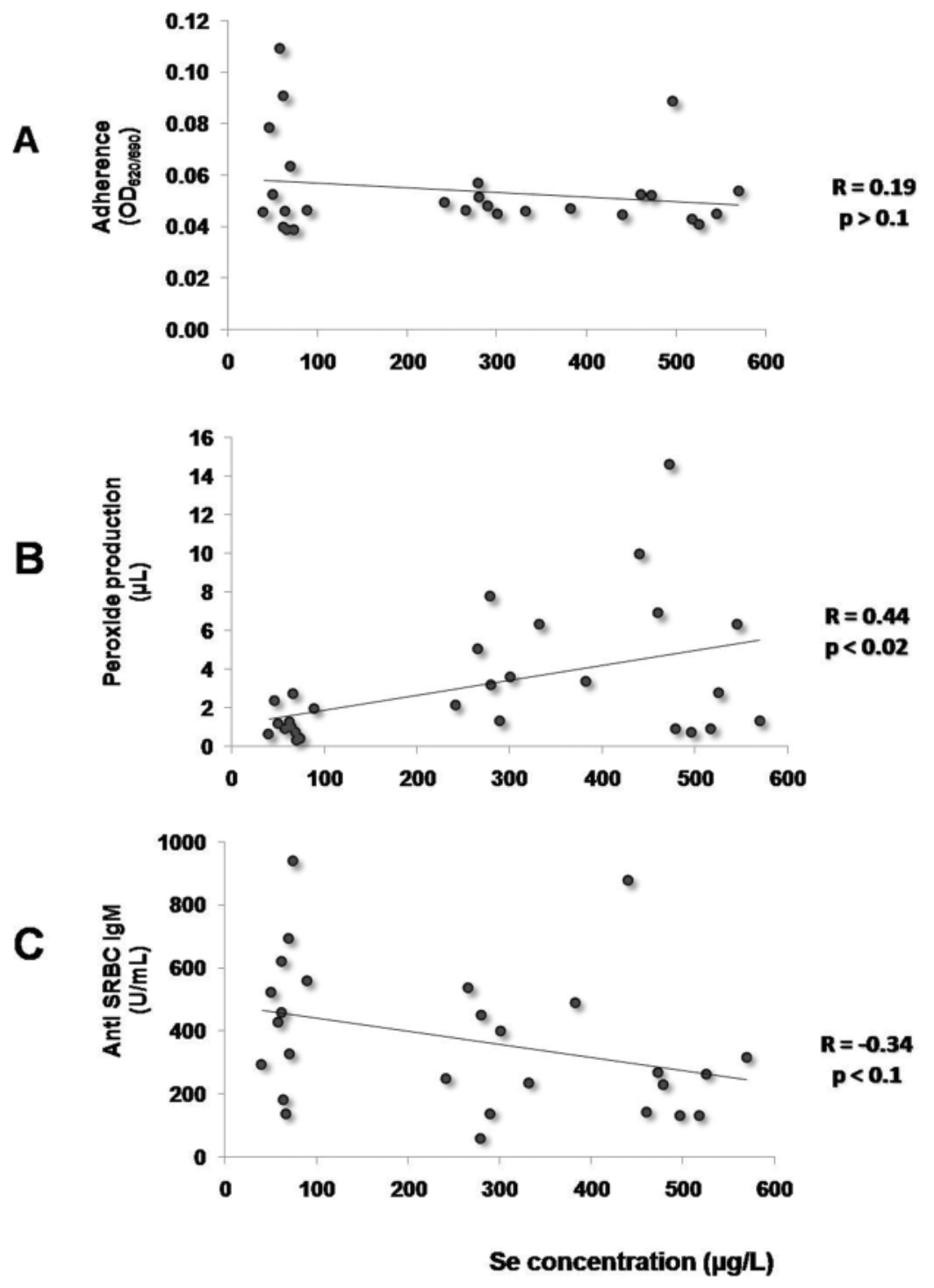

Figure 1. Correlation between blood selenium concentration and macrophages adherence (A) macrophages peroxide production $(\mathrm{C})$ and titer of anti-sheep red blood cells (SRBC) IgM antibodies $(\mathrm{C}) .(\bullet)$ - Experimental data; $(-)$ - Linear regression analysis.

Selenium deficient rats had a significantly higher titer of blood plasma anti-SRBC IgM antibodies comparing to selenium adequate rats (Table 4). The difference in plasma anti-SRBC IgM antibodies titer between PTU- and PTU+ rats was not found. The negative correlation between the titer of anti-SRBC IgM and the blood concentration of selenium was recorded $(\mathrm{R}=-0.34 ; \mathrm{p}=0.08 ; \mathrm{n}=27$ ) (Figure $1 \mathrm{C})$. 
Table 4. Influence of selenium deficiency and PTU on the titer of naturally occurring antiSRBC antibodies.

\begin{tabular}{lcccc}
\hline & \multicolumn{2}{c}{ Selenium adequate } & \multicolumn{2}{c}{ Selenium deficient } \\
\cline { 2 - 5 } & $\begin{array}{c}\text { Euthyroid } \\
(\mathbf{n}=\mathbf{1 2})\end{array}$ & $\begin{array}{c}\text { Hypothyroid } \\
(\mathbf{n}=\mathbf{1 0})\end{array}$ & $\begin{array}{c}\text { Euthyroid } \\
\mathbf{( n = 1 1 )}\end{array}$ & $\begin{array}{c}\text { Hypothyroid } \\
(\mathbf{n}=\mathbf{8})\end{array}$ \\
\hline $\operatorname{IgM}(\mathrm{U} / \mathrm{mL})$ & $254 \pm 240$ & $268 \pm 144$ & $480 \pm 250^{\mathrm{a}}$ & $444 \pm 84^{\mathrm{a}}$ \\
& 182 & 258 & 475 & 465 \\
$\operatorname{IgG}(\mathrm{U} / \mathrm{mL})$ & - & - & - & - \\
\hline
\end{tabular}

The summary data are presented as the mean \pm SD and median. (-) - Below the detection level; (a) $-\mathrm{p}<0.05$ compared to control selenium adequate, euthyroid group.

Titers of anti-SRBC antibodies of IgG class were below the detection level (Table 4).

\section{DISCUSSION}

In this study selenium status was determined on the basis of blood selenium concentration and activity of plasma GPx3 and erythrocyte GPx1. Activities of these enzymes correlate to a high degree with dietary selenium and represent excellent biomarkers for the estimation of selenium status [31]. Based on the measured values of these biomarkers it was estimated that the minimal selenium requirements are 0.06 $\mathrm{mg} \mathrm{Se} / \mathrm{kg}$ feed (for plasma GPx3) and $0.08 \mathrm{mg} / \mathrm{kg}$ feed (erythrocyte GPx1) [32]. In accordance with this it can be concluded that the diet containing $0.33 \mathrm{mg} \mathrm{Se} / \mathrm{kg}$ feed fed to the rats in our experiment ensured the maximal activity of GPx3 and GPx1 in selenium adequate animals. In contrast to this, selenium deficient rats, fed a diet containing ten times less selenium, had approximately six times lower blood selenium concentration $(\mathrm{p}<0.001)$. This result unambiguously confirmed that in our experiment feeding the low selenium diet resulted in its real deficiency. The real selenium deficiency was also confirmed by the results showing that both GPx1 and GPx3 activities were lower in selenium deficient animals. The activity in selenium deficient rats was by $38 \%$ lower compared to the selenium adequate groups. Hill et al. [33] reported that in selenium deficient animals GPx1 declines more rapidly compared to GPx3 which is in agreement to our results where we measured a 65\% decline in GPx1 activity compared to GPx3.

After the three week experimental period concentrations of $\mathrm{T}_{4}, \mathrm{~T}_{3}$ and $\mathrm{TSH}$ in the blood of the euthyroid selenium adequate animals were within the physiological range [34]. It has been proven that PTU induces hypothyroidism in different animal species [35,36] including rats [37]. PTU doses recommended for the induction of hypothyreosis in rats are in the range from $0.01 \%$ to $0.10 \%$ [37]. Thus the PTU dose of $150 \mathrm{mg} / \mathrm{L}$ drinking water $(0.015 \%)$ used in our experiment is sufficient to induce hypothyroidism, which was confirmed by the measured $\mathrm{T}_{4}, \mathrm{~T}_{3}$ and $\mathrm{TSH}$ concentrations in the blood of both selenium adequate and selenium deficient rats. Two possible mechanisms of achieving these effects have been proposed. The first implies the 
inhibition of thyrocytes' peroxidase which oxidases iodine $(\mathrm{I}-1 \rightarrow \mathrm{I} 0)$ and incorporates it into the thyroglobulin tyrosine residues [34]. The second possible mechanism implies the inhibition of iodothyronine deiodinases type-1 which is responsible for the conversion of T4 to T3 [38].

Macrophages as components of innate immunity provide the second line of innate immune defense. During an inflammatory response ROS and cytokine synthesis by tissue resident macrophages activate endothelial cells. Adhesion of circulating monocytes to inflammatory activated endothelial cells and recruitment to an inflamed tissue is the first step in their activation, and it is followed by ROS generation [21-23]. In this study we analyzed the functional characteristics of peritoneal macrophages which were induced i.e. whose number was increased by intraperitoneal injection of sterile thioglycollate solution leading to blood monocytes recruitment $[39,40]$. These obtained "inflammatory macrophages" differ functionally from resident cells and are characterized by a higher plasma membrane turnover, increased capacity for phagocytosis and enhanced respiratory burst. Modulatory effects of thyroid hormones and selenium status on functional properties of the macrophages were studied using two in vitro assays: adherence to plastic (polystyrene) and peroxide production.

The adhesiveness of leukocytes to various matrices (natural or synthetic) has been used for in vitro correlation of leukocyte activation, and the adherence to polystyrene is a widely used assay since the plastic surface behaves physiologically with respect to leukocyte adhesion [29]. Tissue infiltration by blood derived macrophages implies adhesion of circulating monocytes to activated endothelial cells. L-selectin and integrin molecules on circulating monocytes are responsible for this process $[22,23]$. Despite the fact that a significant difference was not found, our results showed that macrophages from selenium adequate rats had a slightly lower level of adhesion. Whether this increased adhesiveness reflects an increased activity of macrophages in selenium deficiency, which can be connected with increased inflammation, is not clear at this moment. The increased adhesiveness of macrophages might be the result of a known "adaptive" mechanisms occurring in selenium deficiency (inhibition of monocyte L-selectin by shedding metalloproteinases and/or stimulation of NF$x \mathrm{~B}$ transcription factors which in turn regulates the synthesis of cyclooxygenase-2, TNF- $\alpha$, IL-1 $\beta$, IL-6, IL8 and adhesive molecules [41] but it cannot be proven without further investigation.

Despite the known fact that hypothyroidism modulates the expression of membranebound and soluble adhesion molecules which regulate lymphocyte and monocyte adherence and trans-endothelial migration $[42,43]$ in this study we did not find that hypothyroidism modulated the adhesion of induced peritoneal macrophages. Without further studies including the analysis of expression of adhesive molecules and analysis of adhesiveness to other matrices (e.g. extracellular matrix proteins) our results cannot be fully explained.

Synthesis of ROS, catalyzed by xanthine oxidases, cyclooxygenases, lipoxygenases, nitric oxide synthase, and mitochondrial oxidases, is one of the multiple mechanisms 
by which macrophages achieve their anti-microbial effects and regulate the activity of cells of both innate and adaptive immunity [44]. It is widely accepted that proinflammatory effects of selenium deficiency resulted from decreased activity of GPx, increase intracellular ROS generation, activate NF- $x \beta$ signaling and accumulate oxidative damages [45]. Therefore, we studied the effects of selenium deficiency and PTU on the synthesis of $\mathrm{H}_{2} \mathrm{O}_{2}$ in thioglycollate induced peritoneal macrophages in a response to in vitro PMA stimulation. $\mathrm{H}_{2} \mathrm{O}_{2}$ synthetized during cell respiratory burst plays a major role in the destruction of the phagocytized microorganisms. In this process, firstly NADPH oxidase complex releases unstable superoxide $\left(\mathrm{O}_{2}^{-}\right)$anions which, spontaneously at low $\mathrm{pH}$ or by the action of the enzyme superoxide dismutase (SOD) are converted into $\mathrm{H}_{2} \mathrm{O}_{2}$.

In our study selenium deficiency resulted in a decreased peroxide production within the rats' macrophages. Our result is in agreement with previously published data $[2,8]$ showing that in in vitro there is a correlation between selenium concentration and peroxide production [46]. In our study such correlation has been confirmed in vivo, as well. The reduced oxidative burst and the subsequent decline in the production of peroxide could be explained by an inadequate metabolism of hydrogen peroxide. A decrease in hydrogen peroxide metabolism can be explained by the decreased GPx activity (detected in this study) resulting in a function loss of membrane bound NADPH oxidase [8]. The physiological significance of our result is not clear and we can only speculate that the reduced $\mathrm{H}_{2} \mathrm{O}_{2}$ synthesis in peritoneal macrophages could be an adaptive mechanism activated during selenium deficiency to protect cells and tissues from oxidative damage. Our results showed that combined selenium deficiency and hypothyroidism resulted in an increased activity of GPx1 compared to selenium deficient euthyroid rats. In order to explain these results, it would be necessary to explain if the lowering peroxide synthesis in the applied experimental conditions were the result of: 1) activation of mechanisms providing priority of preservation of the activity of selenoenzymes members of the antioxidative protection system including thioredoxin reductase; 2) activation of other enzymes of this system (SOD, catalase, hem oxygenase); 3) changed concentrations of non-enzyme components of the system (bilirubin, uric acid, ceruloplasmin, transferine) and/or 4) inhibition of ROS generating enzymes.

In this study we showed that hypothyroidism induced with PTU treatment did not influence $\mathrm{H}_{2} \mathrm{O}_{2}$ synthesis in peritoneal macrophages after in vitro stimulation with PMA. Data on hypothyreosis and macrophage function are not numerous but are similar to our results. Rosa et al. [16] showed that hypothyroidism (similar as hyperthyroidism) did not influence peroxide synthesis in thioglycolate induced macrophages.

Further we analyzed the influence of selenium deficiency or/and hypothyroidism on the titer of naturally occurring anti-SRBC antibodies of IgM classes present in the blood plasma of non-immunized rats. Although immunization with SRBC antigens is widely applied in immune toxicology for the evaluation of T-cell dependent antibody response [47] the antigenic structure of SRBC membranes are complex and besides $\mathrm{T}$ 
dependent antigens express phylogenetically conserved carbohydrate and phospholipid antigens which can be recognized by naturally occurring IgM antibodies secreted in the juvenile rat in absence of apparent antigenic stimulation. The absence of a detectable level of anti-SRBC IgG antibodies and absence of germinal centers in the spleen of any of the analyzed rats (data not shown) indirectly proved that anti-SRBC IgM antibodies belong to a pool of naturally occurring antibodies. In this study we found that hypothyroidism did not influence the titer of anti-SRBC naturally occurring IgM but that selenium deficiency led to an increasing titer of these antibodies. Data on the influence of selenium deficiency on the titer of naturally occurring IgM antibodies are absent in the available literature. The increasing titer of naturally occurring IgM could have a protective role based on their ability to bind and neutralize previously unrecognized microbiological antigens, to induce synthesis of acute phase proteins, to interact with cells of adaptive immune response and stimulate the synthesis of antigen specific IgG, to suppress inflammatory responses mediated by innate or adaptive immune cells, and to prevent autoimmune responses mediated by autoimmune B and T cells [24-26]. However, knowing that selenium deficiency is related to the occurrence and progression of some autoimmune diseases (Hashimoto's thyroiditis, rheumatoid arthritis) $[5,48,49]$ and that some autoantibodies belong to naturally occurring IgM pool augment the pathological immune response [24-26,50], the recorded increased level of naturally occurring $\operatorname{IgM}$ antibodies does not necessarily have a protective role. To completely understand and correctly interpret these results further studies of the effect of selenium on naturally occurring antibodies in animal models of autoimmune diseases using less complex antigen systems are necessary.

In this study, using the applied experimental model of selenium deficiency and PTU induced hypothyroidism in juvenile rats, we did not find that hypothyroidism influences the synthesis of peroxide in peritoneal macrophages or the titer of naturally occurring IgM antibodies. Also we did not find combined effects of selenium deficiency and PTU treatment on the analyzed parameters. The obtained results indicate that selenium, but not thyroid hormones, is of importance for the regulation of the investigated functions of the immune system involved in the recognition and elimination of previously encountered antigens.

\section{Acknowledgement}

This work was supported by TR 31050, III46010, grants from the Ministry of Education, Science and Technological Development of Republic of Serbia.

\section{Authors' contributions}

BJ, IBJ and MS conceived the idea of the study, participated in its design and coordination and helped to draft the manuscript and performed part of the statistical analysis. KD and GD performed statistical data analysis. IV, KD and VO carried out 
the miochemical analyses, participated in the sequence alignment and drafted the manuscript. IV and MS carried out the immunoassays. All authors read and approved the final manuscript.

\section{Declaration of conflicting interests}

The author(s) declared no potential conflicts of interest with respect to the research, authorship, and/or publication of this article.

\section{REFERENCES}

1. McKenzie RC, Arthur JR, Miller SM, Rafferty TS, Beckett GJ: Selenium and the immune system. In: Nutrition and Immune Function, CAB International, Oxford, U.K 2002, 229 250.

2. Arthur JR, Nicol F, Beckett GJ: Hepatic iodothyronine 5' deiodinase. The role of selenium. Biochem J 1990, 272:537-540.

3. Hoffmann PR, Hoge SC, Li PA, Hoffman FV, Hashimoto AC, Berry MJ: The selenoproteome exhibits widely varying, tissue-specific dependence on selenoprotein P for selenium supply, Nucleic Acids Res 2007, 35:3963-3973.

4. Berry MJ, Banu L, Chen YY, Mandel SJ, Kieffer JD, Harney JW, Larsen PR. Recognition of UGA as a selenocysteine codon in type I deiodinase requires sequnces in the 3' untransllated region, Nature 1991, 353, 273-276

5. Tarp U, Overvad K, Hansen JC, Thorling EB: Low selenium level in severe rheumatoid arthritis. Scand J Rheumatol 1985, 14:97-101.

6. Toulis KA, Anastasilakis AD, Tzellos TG, Goulis DG, Kouvelas D: Selenium supplementation in the treatment of Hashimoto's thyroiditis: a systematic review and a meta-analysis. Thyroid 2010, 20:1163-1173.

7. Turner RJ, Finch JM: Selenium and the immune response. Proc Nutr Soc 1991. 50: 275285.

8. Baker SS, Cohen HJ: Altered oxidative metabolism in selenium-deficient rat granulocytes. J Immunol 1983, 130(6):2856-2860

9. Kim SH, Johnson VJ, Shin TY, Sharma RP: Selenium attenuates lipopolysaccharide-induced oxidative stress responses through modulation of p38 MAPK and NF-kappaB signaling pathways. Exp Biol Med (Maywood) 2004, 229:203-13.

10. Huang Z, Aaron A, Hoffmann P: The role of selenium in inflammation and immunity: from molecular mechanisms to therapeutic opportunities. Antioxid Redox Signal 2012, 16:705-743.

11. Kiremidjian-Schumacher L, Roy M, Wishe HI, Cohen MW, Stotzky G: Supplementation with selenium and human immune cell functions. II. Effect on cytotoxic lymphocytes and natural killer cells. Biol Trace Elem Res 1994, 41:115-27.

12. Kiremidjian-Schumacher L, Roy M, Wishe HI, Cohen MW, Stotzky G: Regulation of cellular immune responses by selenium. Biol Trace Elem Res 1992, 33:23-35. 
13. Kiremidjian-Schumacher L, Roy M, Wishe HI, Cohen MW, Stotzky G, Selenium and immune cell functions. I. Effect on lymphocyte proliferation and production of interleukin 1 and interleukin 2. Proc Soc Exp Biol Med 1990, 193:136-42.

14. Roy M, Kiremidjian-Schumacher L, Wishe HI, Cohen MW, Stotzky G: Supplementation with selenium and human immune cell functions. I. Effect on lymphocyte proliferation and interleukin 2 receptor expression. Biol Trace Elem Res 1994, 41:103-14.

15. De Vito P, Incerpi S, Pedersen JZ, Luly P, Davis FB, Davis PJ: Thyroid hormones as modulators of immune activities at the cellular level. Thyroid 2011, 21(8):879-890.

16. Rosa LF, Safi DA, Curi R: Effect of hypo- and hyperthyroidism on the function and metabolism of macrophages in rats. Cell Biochem Funct 1995, 13:141-7.

17. Klecha AJ, Genaro AM, Lysionek AE, Caro RA, Coluccia AG, Cremaschi GA: Experimental evidence pointing to the bidirectional interaction between the immune system and the thyroid axis. Int J Immunopharmacol 2000, 22:491-500

18. Klecha AJ, Genaro AM, Gorelik G, Barreiro Arcos ML, Silberman DM, Schuman M, Garcia SI, Pirola C, Cremaschi GA: Integrative study of hypothalamus-pituitary-thyroidimmune system interaction: thyroid hormone-mediated modulation of lymphocyte activity through the protein kinase C signaling pathway. J Endocrinol. 2006, 189:45-55.

19. Behne D, Kyriakopoulos A, Meinhold H, Köhrle J, 1990, Identification of type I iodothyronine 5'-deiodinase as a selenoenzyme, Biochem Biophys Res Commun, 31, 173(3), 1143-9.

20. Arthur JR, McKenzie RC, Beckett GJ: Selenium in the immune system. J Nutr 2003, 133:1457-9.

21. Abbas AK, Lichtman AH, Pillai S: Cellular and Molecular Immunology (Seventh edition) 2012, Elsevier/ Saunders, Philadelphia, PA, USA.

22. Day MJ, Schultz RD. Veterinary Immunology: Principles and Practice. 2011. Manson publishing/The veterinary press, London, UK.

23. Callahan GN, Yates RM. Basic Veterinary Immunology. 2014. University Press of Colorado, Boulder, Colorado.

24. Boes M: Role of natural and immune IgM antibodies in immune responses. Mol Immunol 2000, 37(18):1141-1149.

25. Grönwall C, Vas J, Silverman GJ: Protective Roles of Natural IgM Antibodies. Front Immunol 2012, 3:66.

26. Lobo PI: Role of natural autoantibodies and natural IgM anti-leucocyte autoantibodies in health and disease. Front Immunol 2016, 7:198.

27. Günzler WA, Steffens GJ, Grossman A, Kim SMA, Otting F, Wendel A, Flohe L: The aminoacid sequence of a bovine glutathione peroxidase. Hoppe-Seyler's Z Physiol Chem 1974, 365:195

28. Sankari: Plasma glutathione peroxidase and tissue selenium response to selenium supplementation in swine. Acta Vet. Scand 1985, 81 (Suppl.):1-127.

29. Oez S, Welte K, Platzer E, Kalden JR: A simple assay for quantifying the inducible adherence of neutrophils. Immunobiology 1990, 180:308-315.

30. Pick E, Mizel D: Rapid microassays for the measurement of superoxide and hydrogen peroxide production by macrophages in culture using an automatic enzyme immunoassay reader. Journal of Immunological Methods 1981, 46:211-226. 
31. Sunde RA: Regulation of glutathione peroxidase-1 expression. In: Hatfield DL, Berry MJ, Gladyshev VN, editors. Selenium: its molecular biology and role in human health. 2nd ed. New York: Springer Science Media 2006, 149-60.

32. Hatfield DL, Selenium: Its molecular biology and role in human health, Kluver academic publishers 2001,

33. Hill K, Burk R, Lane J: Effect of selenium depletion and repletion on plasma glutathione and glutathione dependent enzymes in rat. J Nutr 1987, 117:99-104.

34. Cettour-Rose P, Visser1 TJ, Burger AG, Rohner-Jeanrenaud F: Inhibition of pituitary type 2 deiodinase by reverse triiodothyronine does not alter thyroxine-induced inhibition of thyrotropin secretion in hypothyroid rats. Eur J Endocrinol 2005, 153:429-434.

35. Ferreira E, Silva AE, Serakides R, Gomes AES, Cassali GD: Model of induction of thyroid dysfunctions in adult female mice. Arq Bras Med Vet Zootec 2007, 59:1245-1249.

36. Kabanda L, Lefebvre RA, Van Bree HJ, Remon JP: In vitro and in vivo evaluation in dogs and pigs of a hydrophilic matrix containing propylthiouracil, Pharm Res 1994, 11:16631668.

37. Veronikis IE, Braverman LE, Alex S, Fang SL, Norvell B, Emerson CH: Comparison of the effects of propylthiouracil and selenium deficiency on T3 production in the rat. Endocrinology 1996, 137:2580-2585.

38. Bianco A , Kim B: Deiodinases: Implications of the local control of thyroid hormone action, J Clin Invest 2006, 116:2571-2579.

39. Eichner RD, Smeaton TC: Agar accumulates in rat peritoneal macrophages elicited with thioglycollate broth. Scand J Immunol 1983, 18:259-263

40. Melnicoff MJ, Horan PK, Morahan PS: Kinetics of changes in peritoneal cell populations following acute inflammation. Cell Immunol 1989, 118:178.

41. Tak PP, Firestein GS: NF- ^B: a key role in inflammatory diseases. J Clin Invest 2001, 107:711.

42. Marazuela M, Postigo AA, Acevedo A, Díaz-González F, Sanchez-Madrid F, de Landázuri MO : Adhesion molecules from the LFA-1/ICAM-1,3 and VLA-4/VCAM-1 pathways on T lymphocytes and vascular endothelium in Graves' and Hashimoto's thyroid glands. Eur J Immunol 1994, 24:2483-90.

43. Wenisch C, Myskiw D, Gessl A, Graninger W: Circulating selectins, intercellular adhesion molecule-1, and vascular cell adhesion molecule-1 in hyperthyroidism. J Clin Endocrinol Metab 1995, 80:2122-2126.

44. Cho KJ, Seo JM, Kim JH: Bioactive Lipoxygenase Metabolites Stimulation of NADPH Oxidases and Reactive Oxygen Species. Mol Cells 2011, 32(1):1-5.

45. Duntas LH: Selenium and Inflammation: Underlying anti-inflammatory mechanisms. Horm Metab Res 2009, 41:443-447.

46. Vunta H, Davis F, Palempalli U, Bhat D, Arner R, Thompson J, Peterson D, Reddy C, Prabhu KS: The Anti-inflammatory Effects of Selenium Are Mediated through 15-Deoxy$\Delta$ 12,14-prostaglandin J2 in Macrophages. J Biol Chem 2007, 282:17964-17973.

47. Ladics GS: Primary immune response to sheep red blood cells (SRBC) as the conventional T-Cell dependent antibody response (TDAR) test. J Immunotox 2007, 4:149-152.

48. Witkowska AM, Kuryliszyn-Moskal A, Borawska MH, Hukałowicz K, Markiewicz R: A study on soluble intercellular adhesion molecule-1 and selenium in patients with rheumatoid arthritis complicated by vasculitis. Clin Rheumatol 2003, 22:414-419. 
49. Duntas LH: The Role of Iodine and Selenium in Autoimmune Thyroiditis. Horm Metab Res 2015, 47(10):721-726.

50. Li J, Liang Y, Mao H, Deng W, Zhang J: Effects of B-lymphocyte dysfunction on the serum copper, selenium and zinc levels of rheumatoid arthritis patients. Pak J Med Sci 2014, 30:1064-1067.

\title{
UTICAJ DEFICITA SELENA I TIROIDNIH HORMONA NA ATHEZIJU PERITONEALNIH MAKROFAGA I PRIRODNA IgM ANTITELA KOD JUVENILNIH PACOVA
}

\author{
BJELICA Jelena, JOVANOVIĆ Ivan B, ILIĆ Vesna, VALČIĆ Olivera, KIROVSKI \\ Danijela, GVOZDIĆ Dragan, MILANOVIĆ Svetlana
}

Selen kao efektor i regulator enzima antioksidativne zaštite, kao i hormoni tiroidne osovine su snažni imunomodulatori. Pored toga, selen, kao sastavni element enzima jodotirozin dejodinaza direktno reguliše aktivnost hormona tiroidne železde, a time indirektno reguliše imunski odgovor. Studije o njihovom uzajamnom dejstvu na regulaciju imunskog odgovora skoro da ne postoje. U ovom radu smo analizirali uticaj propiltiouracila (PTU), blokatora dejodinaza i deficit selena na funciju peritonealnih makrofaga i titar prirodnih IgM antitela kod juvenilnih pacova. Studija je rađena na mužjacima Wistar pacova ( $\mathrm{n}=64)$ koji su bili podeljeni u četiri grupe: kontrolna grupa, selenadekvatni, PTU-; selenadekvatni, PTU+; selendeficitni, PTU- i selendeficitni, PTU+. Selenadekvatni i selendeficitni pacovi su dobijali hranu koja je sadržala 0.334 odnosno 0,031 mg Se/kg. PTU je davan rastvoren u vodi za piće u koncentraciji 150 $\mathrm{mg} / \mathrm{L}$. Posle tri nedelje tretmana odredivan je nivo tiroksina (T4), trijodtironina (T3) i tireostimulirajućeg hormona (TSH). Životinje koje su imale intermedijalne koncentracije T3 (1,56-1,69 nmol/L) i T4 (41-50 nmol/L) su isključene iz daljih analiza. Tako su PTU+ grupe činile isključivo hipotiroidne jedinke (T3 $\leq 1,55 \mathrm{nmol} / \mathrm{L} ; \mathrm{T} 4 \leq 40 \mathrm{nmol} / \mathrm{L})$, dok su PTU- grupe činile eutiroidne jedinke (T3 $\geq 1,70 \mathrm{nmol} / \mathrm{L} ; \mathrm{T} 4 \geq 50 \mathrm{nmol} / \mathrm{L})$. Obe grupe selendeficitnih pacova su imale nižu aktivnost glutation peroksidaza GPx1 i GPx3 u odnosu na kontrolnu grupu životinja. Ni deficit selena ni PTU nisu uticali na adherencu peritonealnih makrofaga. Defict selena je značajno smanjio sintezu peroksida u makrofagama i doveo do povećanja titra IgM antitela na ovčje eritrocite. Sam hipotiroidizam ili u kombinaciji sa deficitom selena nije uticao na ove parametre. 